\title{
Electrochemical Stability and Bioactivity Evaluation of Ti6AI4V Surface Coated with Thin Oxide by EIS for Biomedical Applications
}

\author{
Bruno Schneider Gugelmin ${ }^{a}$, Luciane Sopchenski Santos ${ }^{a}$, \\ Haroldo de Araújo Ponte ${ }^{b}$, Cláudia Eliana Bruno Marino ${ }^{c *}$ \\ aPrograma de Pós-Graduação em Engenharia e Ciência de Materiais, Universidade Federal do Paraná \\ - UFPR, CP 19011, CEP 81531-900, Curitiba, PR, Brazil \\ ${ }^{b}$ Departamento de Engenharia Química, Universidade Federal do Paraná - UFPR, \\ CP 19011, CEP 81531-900, Curitiba, PR, Brazil \\ 'Departamento de Engenharia Mecânica, Universidade Federal do Paraná - UFPR, \\ CP 19011, CEP 81531-900, Curitiba, PR, Brazil
}

Received: April 1, 2015; Revised: April 29, 2015

\begin{abstract}
To improve the implants biocompatibility many surface modifications were proposed. Investigations about the surface modification on Ti alloys by anodic oxidation are reported. This research presents a study on the stability of thin titanium dioxide grown by potentiodynamic method on Ti6Al4V surfaces up to $5.0 \mathrm{~V}$. Its bioactive surface in phosphate buffer solution (PBS) and the oxide stability after immersion in artificial blood media were measured by Electrochemical Impedance Spectroscopy (EIS). Hydroxyapatite (HAP) presence was evaluated using simulated body fluid (SBF) with different immersion times. The oxides and HAP presence were analyzed by Scanning Electron Microscopy (SEM) and X-ray Photoelectron Spectroscopy (XPS). The oxide stability was confirmed with low dissolution rates where the Rp was around $10^{6} \Omega . \mathrm{cm}^{2}$. The results showed the $\mathrm{TiO}_{2}$ was compact and thin oxide that could prevent the severe corrosion processes and improve in few days the physicalchemical interaction of the Ti alloys with bone in physiological media.
\end{abstract}

Keywords: Ti6Al4V, thin films, EIS, bioactivity

\section{Introduction}

Titanium is an important material in use for surgical purposes when compared to stainless steel and cobalt-chromium alloys. Due to its attractive mechanical and chemical characteristics and its property of "biofixation" with the periprosthetic tissue, titanium metal is established as one of the major materials used for manufacturing of orthopedic implants ${ }^{1}$. The good corrosion resistance of $\mathrm{Ti}$ and $\mathrm{Ti}$ alloys results from the presence of stable, continuous, highly adherent and protective oxide films on the metal surface (thickness 1 to $4 \mathrm{~nm})^{[2,3]}$.

In order to improve the corrosion behavior, mechanical properties, biocompatibility and osseointegration efficiency, numerous surface modifications have been studied ${ }^{4-6}$. Oxidized implants change the properties of the titanium implant and play an important role during the dynamic build-up of the osseointegration process ${ }^{7}$.

In the anodic oxidation of titanium, high potentials (around $300 \mathrm{~V}$ ) are often used, by potentiostatic or galvanostatic methods, leading to dielectric breakdown ${ }^{5,8-10}$. Furthermore, the uses of acid media and with higher concentration electrolytes are common ${ }^{11-13}$.

Kuphasuk et al. studied the electrochemical behavior of Ti, Ti6Al4V, NiTi and three other titanium alloys at $37^{\circ} \mathrm{C}$ in Ringer's solution ${ }^{14}$. Electron diffraction patterns indicated that all titanium alloys were covered mainly with rutile-type

*e-mail: claudiamarino@ufpr.br oxide after corrosion tests and the $\mathrm{Ti}$ and $\mathrm{Ti} 5 \mathrm{Al} 2.5 \mathrm{Fe}$ were the most resistant to corrosion. The stability of anodic films grown on titanium materials was studied in a physiological electrolyte, up to $8.0 \mathrm{~V}$, where thin titanium oxide films protect the surface of the Ti6Al4V alloy up to $6.0 \mathrm{~V}$, after which localized corrosion then starts to occur ${ }^{15}$.

The electrochemical property of the oxide film and its long-term stability in biological environments plays a decisive role for the biocompatibility of titanium implants. The oxide films on metal surfaces have been characterized by Electrochemical Impedance Spectroscopy (EIS) ${ }^{7,16-18}$. This method consists of the system response to the application of a periodic small amplitude $a c$ signal. The measurements are carried out at different $a c$ frequencies. These analyses contain information about the interface, its structure, porous presence, sealing process and various parallel reactions ${ }^{19,20}$.

Marino and Mascaro investigated the electrochemical behavior and its long term stability of Ti-grade 2 oxides in PBS solution and artificial saliva by electrochemical impedance spectroscopy (EIS). The impedance response indicated a slight dissolution of the thin oxide film on dental implants during the immersion times ${ }^{15}$. By EIS, the Ti and TiMo were investigated and high impedance values were obtained, increasing with immersion time, indicating an improvement in corrosion resistance of spontaneous oxide film in the case of $\mathrm{TiMo}^{21}$. 
Ti6A14V and Ti13Nb13Zr were analyzed in Ringer solution at different $\mathrm{pH}$ values by EIS and pontentiodynamic techniques where both alloys presented anodic film with two layers: one compact and the other porous, independent of the $\mathrm{pH}$ value ${ }^{22}$. Also EIS diagrams detected a two-layered oxide film comprised of a porous outer layer and a compact inner layer ${ }^{23}$.

The biocompatibility of titanium and its alloys depends on the surface chemical composition and the ability of titanium oxide to absorb molecules and incorporate elements. The surface containing $\mathrm{Ca}$ and $\mathrm{P}$ leads to osseoinduction of new bones and becomes bioactive. The $\mathrm{Ca} / \mathrm{P}$ ratio should be near 1.67 in the anodic film to represent a bioactive surface ${ }^{24-26}$. Bioactivity can be evaluated by in vitro tests. Kokubo's group used the immersion test in Simulated Body Fluid (SBF) as a bone deposition parameter ${ }^{27}$. The crystal structure and surface morphology of the titanium oxide films were investigated in SBF to apatite-forming ability. The rutile and anatase structure could be inducing the apatite deposition because of the lattice between these forms of oxide and apatite ${ }^{28}$.

The topography was studied by Zhu et al. and the composition and structure of the titanium anodic films in calcium glycerophosphate and calcium acetate resulted in a porous and crystalline oxide rich in $\mathrm{Ca}$ and $\mathrm{P}^{24}$.

The aim of this research is to investigate the electrochemical treatment and bioactivity of a very thin oxide film grown by potentiodynamic method on Ti6Al4V orthopedic implants by EIS (Electrochemical Impedance Spectroscopy) technique.

\section{Material and Methods}

Disks made from commercial Ti6Al4V - Company Realum Ind. e Com.-Pure Metals and Alloys. The electrodes $(2.0 \mathrm{~cm}$-diameter and $0.5 \mathrm{~cm}$-thick) were mechanically polished with silicon carbide paper of grade 1200 and rinsed with acetone, ethanol and distilled water. The anodic oxides covering the Ti6Al4V rods were obtained under potentiodynamic conditions at initial $(\mathrm{Ei})$ and final $\left(\mathrm{E}_{\mathrm{f}}\right)$ potentials of $-1.0 \mathrm{~V}$ to $5.0 \mathrm{~V}$ ( $v S$ SCE), respectively, in phosphate buffer solution (PBS) with $\mathrm{Cl}^{-}$ion concentration about 0.14 mol.L-1 (ASTM F2129-8 pH 6.9; $\mathrm{NaCl} 8.77 \mathrm{~g} \mathrm{~L}^{-1}$; $\left.\mathrm{Na}_{2} \mathrm{HPO}_{4} 3.58 \mathrm{~g} \mathrm{~L}^{-1} ; \mathrm{KH}_{2} \mathrm{PO}_{4} 1.36 \mathrm{~g} \mathrm{~L}^{-1}\right)^{[29]}$.

The scan rate equal to $50 \mathrm{mV} \cdot \mathrm{s}^{-1}$ was applied, in a conventional electrochemical system with three electrodes: Saturated Calomel Electrode (SCE) as a reference electrode, Pt electrode as an auxiliary electrode and Ti6Al4V rods as a work electrode (exposed area: $0.28 \mathrm{~cm}^{2}$ ).

The EIS measurement was carried out using a Voltalab 40 (PGZ301), Radiometer equipment. For impedance data acquisition the amplitude of the sinusoidal signal was $25 \mathrm{mV}$ and the frequency range was $100 \mathrm{kHz}$ to $100 \mathrm{mHz}$. Impedance spectra were obtained at the open-circuit potential (OCP) in phosphate buffer solution (ASTM F2129-8 $\mathrm{pH}$ 6.9; $\left.\mathrm{NaCl} 8.77 \mathrm{~g} \mathrm{~L}^{-1} ; \mathrm{Na}_{2} \mathrm{HPO}_{4} 3.58 \mathrm{~g} \mathrm{~L}^{-1} ; \mathrm{KH}_{2} \mathrm{PO}_{4} 1.36 \mathrm{~g} \mathrm{~L}^{-1}\right)^{[29]}$.

For the stability studies, artificial blood media was used (ASTM F2129-8 pH 7.3; $\mathrm{NaCl} 6.80 \mathrm{~g} \mathrm{~L}^{-1}, \mathrm{KCl} 0.40 \mathrm{~g} \mathrm{~L}^{-1}$, $\mathrm{CaCl}_{2} \cdot \mathrm{H}_{2} \mathrm{O} 0.20 \mathrm{~g} \mathrm{~L}^{-1}, \mathrm{NaH}_{2} \mathrm{PO}_{4} \cdot \mathrm{H}_{2} \mathrm{O} 0.02 \mathrm{~g} \mathrm{~L}^{-1}, \mathrm{Na}_{2} \mathrm{HPO}_{4}$. $\left.\mathrm{H}_{2} \mathrm{O} 0.126 \mathrm{~g} \mathrm{~L}^{-1}, \mathrm{MgSO}_{4} 0.10 \mathrm{~g} \mathrm{~L}^{-1}, \mathrm{NaHCO}_{3} 2.20 \mathrm{~g} \mathrm{~L}^{-1}\right)^{[29]}$ at different immersion times: 1 hour, 10, 30 and 90 days. All electrochemical tests were performed in triplicate and kept at room $\left(\sim 25^{\circ} \mathrm{C}\right)$ temperature.
For the analysis of the bioactive response (Hydroxyapatite-HAP presence) was used the biomimetic test at body temperature $\left(\sim 37^{\circ} \mathrm{C}\right)$. The electrolyte was the SBF media $\mathrm{NaCl} 8.035 \mathrm{~g} \mathrm{~L}^{-1}$, $\mathrm{NaHCO}_{3} 0.355 \mathrm{~g} \mathrm{~L}^{-1}, \mathrm{KCl} 0.225 \mathrm{~g} \mathrm{~L}^{-1}, \mathrm{~K}_{2} \mathrm{HPO}_{4} \cdot 3 \mathrm{H}_{2} 00.231 \mathrm{~g} \mathrm{~L}^{-1}$, $\mathrm{MgCl}_{2} \cdot 6 \mathrm{H}_{2} 00.311 \mathrm{~g} \mathrm{~L}^{-1}, \mathrm{HCl} 1 \mathrm{~mol} . \mathrm{L}^{-1} 39 \mathrm{~mL}, \mathrm{CaCl}_{2} 0.292$ $\mathrm{g} \mathrm{L}^{-1}, \mathrm{Na}_{2} \mathrm{SO}_{4} 0.072 \mathrm{~g} \mathrm{~L}^{-1}$, TRIS $\mathrm{C}_{4} \mathrm{H}_{11} \mathrm{NO}_{3}$ to adjust $\mathrm{pH}$ 7.4) for 10 days of immersion time ${ }^{27}$. The semi-quantitative analysis was determinate by $\mathrm{X}$-ray photoelectron spectroscopy (XPS) using a Kratos Analytical XSAM HS Spectrometer having a $\mathrm{Mg} \mathrm{K} \alpha(\mathrm{h} v=1253.6 \mathrm{eV})$. X-ray source with power given by the emission of $15 \mathrm{~mA}$ at a voltage of $15 \mathrm{kV}$. The high-resolution spectra were obtained with analyzer energy of $20 \mathrm{eV}$. The binding energies were referred to the carbon $1 \mathrm{~s}$ line, set at $284.8 \mathrm{eV}$. A least-square routine was used for the fitting of the peaks. By Scanning Electron Microscopy (SEM) (Philips, model XL 30 and $20.0 \mathrm{kV}$ ) was observed the surface morphologies of the samples.

\section{Results and Discussion}

Potentiodynamic profiles were registered when the oxide layers were grown on the surface at 5.0 V, Figure 1-curve a. The samples were also analyzed after different immersion times in artificial blood media, when the oxide layer was reconstructed, Figure 1-curve b. Some dissolution was detected from the area under the curves according to Faraday's Law $(\mathrm{Q}=\mathrm{i} . \mathrm{t})$. The anodic charges related to the formation (curve a) and reconstruction (curve b) of the oxide film allow the evaluation of the magnitude of these processes. These charges were obtained by integration of the corresponding I (current density) vs. E (potential) curves (Figure 1). Although it was low, with minimal reconstructive charges, it is on the order of $10 \mathrm{mC}$.

The orthopedic alloy Ti6Al4V has a metal valve behavior, in which there is a protective oxide that hardly reduced in the potentiodynamic process. As described in Marino's research ${ }^{2}$ with anodic charges of the Ti-oxide growth, the anodization rate was determined by electrochemical methods and was found to $2.5 \mathrm{~nm} / \mathrm{V}$. Thus, considering this anodization rate, the oxide thickness grown until $5.0 \mathrm{~V}$ is $\sim 12.5 \mathrm{~nm}^{2,15}$. This

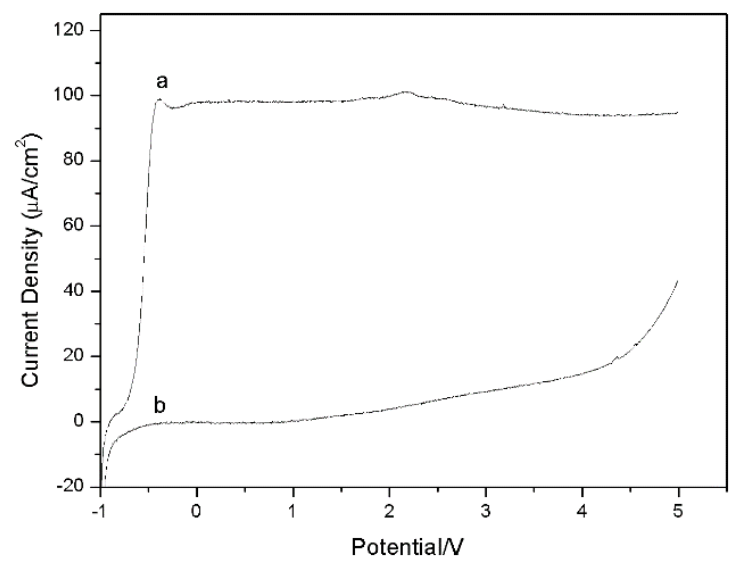

Figure 1. Ti6Al4V surface potentiodynamic curves of oxide growth (a) and reconstruction (b) in PBS solution at 5.0 V, before (a) and after (b) 30 days in artificial blood at room temperature. 
behavior provides a better stability and protection to the bulk when immersed in physiological environment.

The Table 1 shows the reconstruction percentage varied with the immersion time in artificial blood solution. The reconstruction degree is equal to the ratio between reconstruction charge (by integration of curve b-Figure 1) and formation charge (by integration of curve a-Figure 1). It's possible to observe that after the immersion process in artificial blood was required a significant of the oxide layer reconstruction due to the presence of aggressive chloride ions. The highest reconstruction percentage for the oxides grown in $5.0 \mathrm{~V}$ was $18.1 \%$ (after 30 days). After 90 days there was a decrease in the dissolution process, suggesting the pores were sealed ${ }^{30}$.

The impedance spectra for the oxide before and after immersion in artificial blood are presented in Figure 2. It is possible to observe an incomplete semi-circle over all the frequency range indicating a highly resistive surface.

The low capacitive value (around $15 \mu \mathrm{F} . \mathrm{cm}^{-2}$ ) denotes the presence of a thin and compact oxide. The polarization resistance $\left(R_{p}\right)$ was estimated by the impedance values from the high frequencies to the real axis (low frequencies region). After the immersion in artificial blood the $\mathrm{R}_{\mathrm{p}}$ decreased from $62.810^{6} \Omega . \mathrm{cm}^{2}$ to $2.610^{5} \Omega . \mathrm{cm}^{2}$, resulting most likely from the spontaneous oxide dissolution. This result was confirmed by the oxide reconstruction rate submitted to the open circuit analyses for 30 days. This dissolution process can be originated both from the oxide thickness decrease as the matrix rearrangement occurs during the electrolyte exposure $^{21,31}$.

Comparing the impedance spectra from the Ti6Al4V alloy and from the pure titanium, it is possible to suppose they have distinct electric behaviors ${ }^{14,23}$. For pure titanium, two time constants are observed, arisen from the internal (compact) and external (porous) oxide layers according to the bi-layer oxide model ${ }^{20,32}$. As described previously, the protective oxide layer formed over the Ti6Al4V alloy is formed from $\mathrm{TiO}_{2}$ and is also a bi-layer oxide ${ }^{7,33,34}$. However, it is not possible to observe these two time constants for the Ti6Al4V alloy (Figure 3 ). This could denote a very close relaxation time $(100 \mathrm{~Hz}$ e $10 \mathrm{~Hz})$ for the two processes ${ }^{35}$.

The morphologies of all samples were analyzed by SEM. The Ti alloy surface covered with $\mathrm{TiO}_{2}$ grown up to $5.0 \mathrm{~V}$ is presented in Figure $4 \mathrm{a}$. It is possible to observe a non-defined morphology without the presence of pores. Samples immersed in SBF (at body temperature) during ten days showed the typical globular morphology of HAP, Figure $4 \mathrm{~b}$. The presence of a thin layer of HAP increases the resistance to corrosion and improves the osseointegration process $^{12,24,26,36}$.

X-ray photoelectron spectroscopy (XPS) analysis showed the presence of $\mathrm{TiO}_{2}$ and the HAP layer basically on its surface in SBF (Table 2). The ratio $\mathrm{Ca} / \mathrm{P}$ of the film was found to be 1.6 , a value very close to the biological response, which is around $1.67^{[24,26,36]}$.

In summary, the best physical-chemical interaction between HAP and the $\mathrm{TiO}_{2}$ obtained potentiodynamically happens in only 10 days. Probably, the $\mathrm{TiO}_{2}$ recombines with $\mathrm{OH}^{-}$ions from the aqueous solution, resulting in a
Table 1. Reconstruction degree of oxide film on Ti6Al4V after immersion tests in artificial blood solution at room temperature.

\begin{tabular}{cc}
\hline Immersion Time & Reconstruction Degree \\
\hline 1 hour & $2.0 \%$ \\
10 days & $13.1 \%$ \\
30 days & $18.1 \%$ \\
90 days & $13.8 \%$ \\
\hline
\end{tabular}

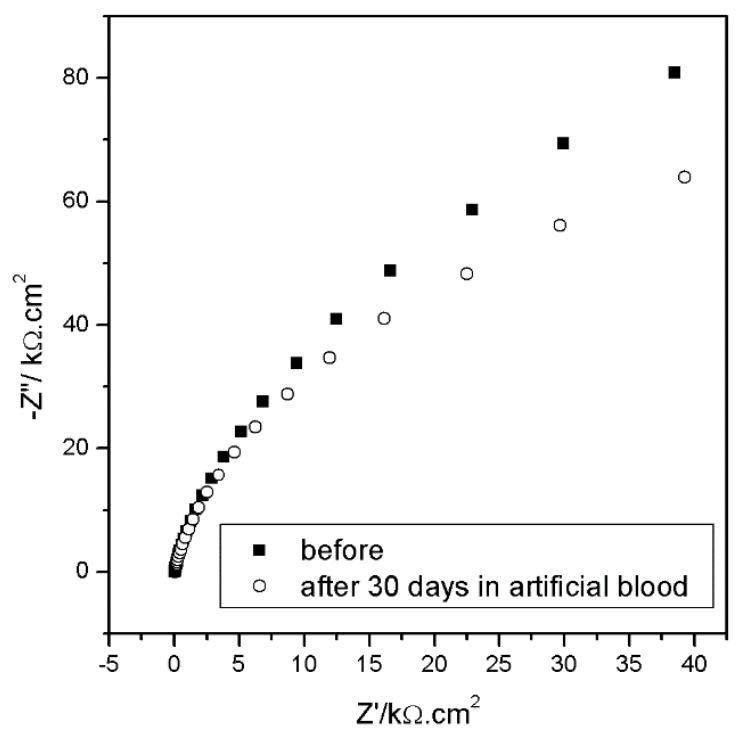

Figure 2. Nyquist plot for Ti6Al4V/oxide grown at 5.0 V in PBS before and after immersion in artificial blood for 30 days at room temperature. The $d c$ potential was the open circuit potential: $\sim 0.380 \mathrm{~V}$.

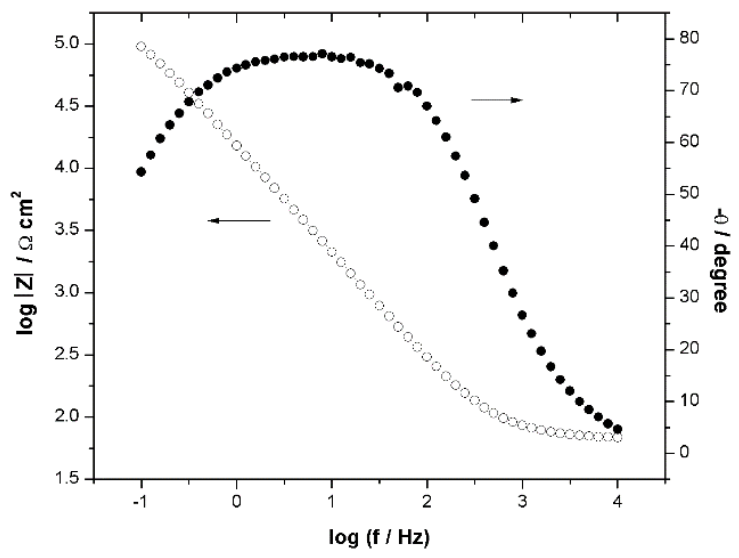

Figure 3. Bode impedance plot for Ti6A14V/oxide system. The $d c$ potential was the open circuit potential: $\sim 0.380 \mathrm{~V}$ at room temperature.

TiOOH species that provides a uniform and homogeneous HAP layer ${ }^{5,11,25}$.

Electrochemical impedance has been shown to be an attractive technique for studying metallic biomaterials. The impedance data will be compared in order to evaluate the influence of the HAP presence on the thin passive oxide stability.

Impedance spectra for Ti6Al4V at different immersion times (1, 3, 5, 7 and 10 days) in SBF solution at body 


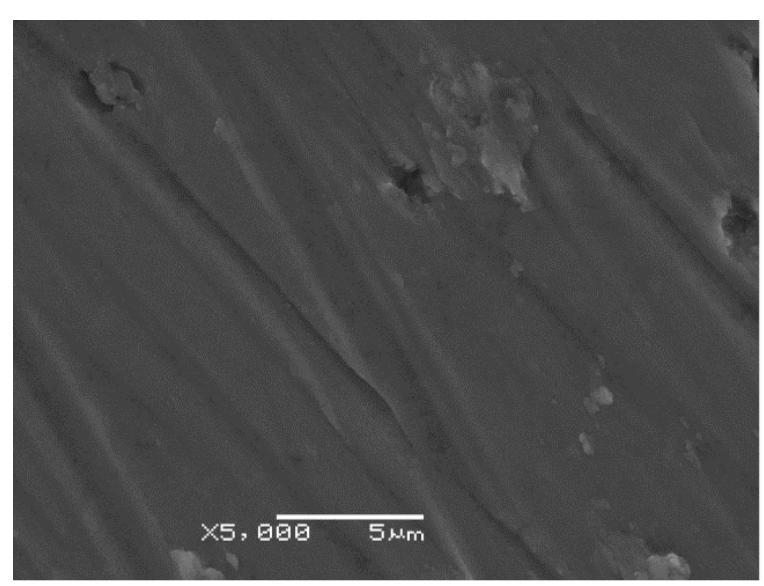

(a)

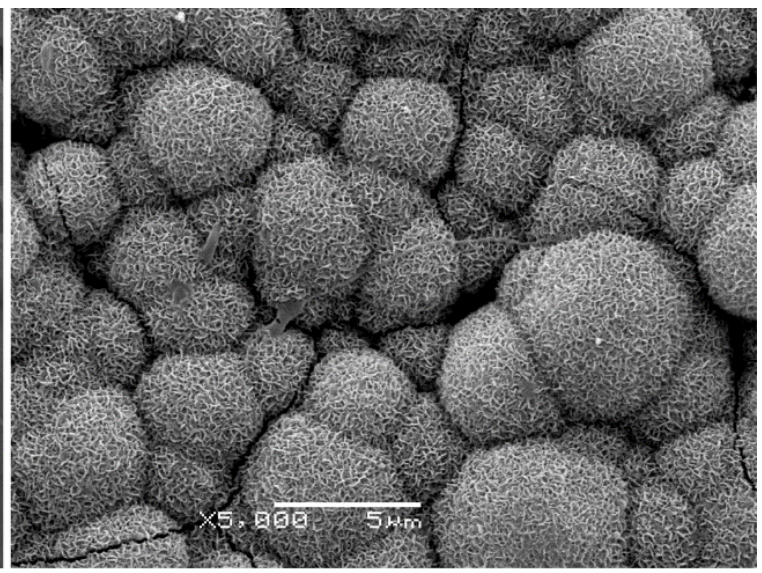

(b)

Figure 4. SEM image of Ti6Al4V with $\mathrm{TiO}_{2}$ grown until $5.0 \mathrm{~V}$ (a) before and (b) after 10 days of immersion in SBF at body temperature. The globular morphology is characteristic from the HAP presence.

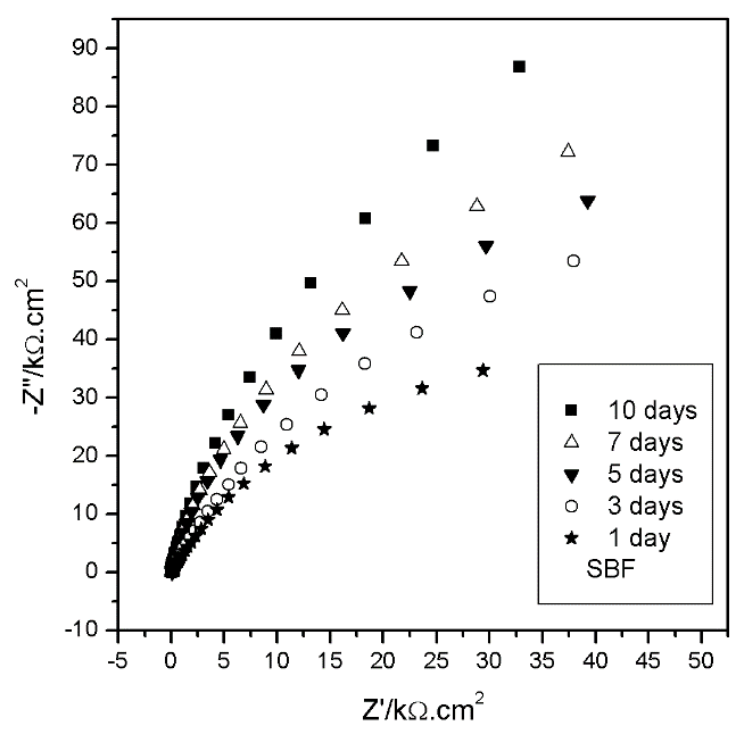

Figure 5. Nyquist plot for Ti6A14V/oxide system after different immersions time in SBF at body temperature. The $d c$ potential was the open circuit potential: $\sim 0.380 \mathrm{~V}$.

Table 2. Chemical composition of $\mathrm{Ti} 6 \mathrm{Al} 4 \mathrm{~V} / \mathrm{TiO}_{2} / \mathrm{HAP}$ surface investigated by X-ray photoelectron spectroscopy (at.\%).

\begin{tabular}{cc}
\hline Element & Atomic Concentration \\
\hline Ti $2 p$ & $14.58 \%$ \\
O $1 \mathrm{~s}$ & $52.26 \%$ \\
Ca $2 p$ & $3.29 \%$ \\
P $2 p$ & $2.06 \%$ \\
\hline
\end{tabular}

temperature are represented as Nyquist plots, exemplified in Figure 5.

These profiles exhibit a similar impedance behavior with the immersion time indicating a resistive system. However, there is a significant increase in their polarization resistance value after 1 day, $\mathrm{R}_{\mathrm{p}}=10^{5} \Omega . \mathrm{cm}^{2}$ and after 10 days,
$\mathrm{R}_{\mathrm{p}}=10^{6} \Omega \cdot \mathrm{cm}^{2}$. This result could be due to the spontaneous hydroxyapatite layer on the Ti6Al4V surface recovered with passive film.

The Nyquist diagram shows a capacitive loop with one time constant. This fact could indicate a compact non-conductive layer that would consist of $\mathrm{TiO}_{2}{ }^{[20]}$ and HAP. The low capacitance value around $15 \mu \mathrm{F} . \mathrm{cm}^{-2}$ confirms the compact and thin oxide presence ${ }^{15,16}$ and could indicate a long-term stability of this passive film with HAP presence on the implant surface. This anodic film has a promising positive biological response.

\section{Conclusion}

The Ti6Al4V alloy can be recovered by a thin $(\sim 12.5 \mathrm{~nm})$, stable (less than $13 \%$ dissolution rate in aggressive media) and compact $\left(\mathrm{Rp}=10^{6} \Omega . \mathrm{cm}^{2}\right.$ and $\left.\mathrm{C}=15 \mu \mathrm{F} . \mathrm{cm}^{-2}\right)$ oxide layer obtained potentiodynamically. After only10 days in SBF immersion a uniform deposition of HAP was observed, indicating that a simple electrochemical treatment can minimize the dissolution process and facilitate the physical-chemical interaction between bone and implant. The electrochemical treatment could be an effective method for the stability and bioactivity Ti6Al4V alloy. By EIS was possible to study the initial stage of the hydroxyapatite presence because this specific technique allows detecting the electrochemical and deposition processes separately. In addition, we found the HPA presence under only few days (10 days) with a considerable stability.

\section{Acknowledgements}

The authors are grateful to PIPE-UFPR (Graduate Program of Engineering and Materials Science), the Laboratory of Biomaterials and Electrochemistry (Department of Mechanical Engineering/UFPR) and the Erasto Gaertner Bioengineering Institute. Finally, we would like to thank $\mathrm{CNPq}$ for the productivity fellowship (CNPq - Grant number 301434/2013-1) to Cláudia Eliana Bruno Marino. 


\section{References}

1. McCracken M. Dental implant materials: commercially pure titanium and titanium alloys. Journal of Prosthodontics: Official Journal of the American College of Prosthodontists. 1999; 8(1):40-43. http://dx.doi.org/10.1111/j.1532-849X.1999. tb00006.x. PMid:10356553.

2. Marino CEB, Oliveira EM, Rocha-Filho RC and Biaggio SR. On the stability of thin-anodic-oxide films of titanium in acid phosphoric media. Corrosion Science. 2001; 43(8):1465-1476. http://dx.doi.org/10.1016/S0010-938X(00)00162-1.

3. Kadowaki NT, Martinez GAS and Robin A. Electrochemical behavior of three CP titanium dental implants in artificial saliva. Materials Research. 2009; 12(3):363-366. http://dx.doi. org/10.1590/S1516-14392009000300018.

4. Quintero D, Galvis O, Calderón JA, Castaño JV and Echeverría F. Effect of electrochemical parameters on the formation of anodic films on commercially pure titanium by plasma electrolytic oxidation. Surface and Coatings Technology. 2014; 258:12231231. http://dx.doi.org/10.1016/j.surfcoat.2014.06.058.

5. Szesz EM, Pereira BL, Kuromoto NK, Marino CEB, Souza GB and Soares PC. Electrochemical and morphological analyses on the titanium surface modified by shot blasting and anodic oxidation process. Thin Solid Films. 2013; 528:163-166. http:// dx.doi.org/10.1016/j.tsf.2012.09.096.

6. Park IS, Woo TG, Jeon WY, Park HH, Lee MH, Bae TS, et al. Surface characteristics of titanium anodized in the four different types of electrolyte. Electrochimica Acta. 2007; 53(2):863-870. http://dx.doi.org/10.1016/j.electacta.2007.07.067.

7. Milošev I, Metikos-Huković M and Strehblow H-H. Passive film on orthopaedic TiAlV alloy formed in physiological solution investigated by X-ray photoelectron spectroscopy. Biomaterials. 2000; 21(20):2103-2113. http://dx.doi.org/10.1016/ S0142-9612(00)00145-9. PMid:10966021.

8. Yang B, Uchida M, Kim HM, Zhang X and Kokubo T. Preparation of bioactive titanium metal via anodic oxidation treatment. Biomaterials. 2004; 25(6):1003-1010. http://dx.doi. org/10.1016/S0142-9612(03)00626-4. PMid:14615165.

9. Chen JZ, Shi YL, Wang L, Yan FY and Zhang FQ. Preparation and properties of hydroxyapatite-containing titania coating by micro-arc oxidation. Materials Letters. 2006; 60(20):2538-2543. http://dx.doi.org/10.1016/j.matlet.2006.01.035.

10. Oh HJ, Lee JH, Kim YJ, Suh SJ, Lee JH and Chi CS. Surface characteristics of porous anodic $\mathrm{TiO} 2$ layer for biomedical application. Materials Chemistry and Physics. 2008; 109(1):1014. http://dx.doi.org/10.1016/j.matchemphys.2007.11.022.

11. Cui X, Kim HM, Kawashita M, Wang L, Xiong T, Kokubo T, et al. Preparation of bioactive titania films on titanium metal via anodic oxidation. Dental materials : official publication of the Academy of Dental Materials. 2009; 25(1):80-86. http:// dx.doi.org/10.1016/j.dental.2008.04.012. PMid:18599115.

12. Park JW, Park KB and Suh JY. Effects of calcium ion incorporation on bone healing of Ti6Al4V alloy implants in rabbit tibiae. Biomaterials. 2007; 28(22):3306-3313. http:// dx.doi.org/10.1016/j.biomaterials.2007.04.007. PMid:17462729.

13. An S, Matsumoto T, Sasaki J, Miyajima H, Narayanan R, Imazato $\mathrm{S}$, et al. In vitro bioactivity evaluation of nano- and micro-crystalline anodic TiO2 : HA formation, cellular affinity and organ culture. Materials Science and Engineering: C. 2012; 32(8):2516-2522. http://dx.doi.org/10.1016/j.msec.2012.07.034.

14. Kuphasuk C, Oshida Y, Andres CJ, Hovijitra ST, Barco MT and Brown DT. Electrochemical corrosion of titanium and titanium-based alloys. The Journal of Prosthetic Dentistry. 2001;
85(2):195-202. http://dx.doi.org/10.1067/mpr.2001.113029. PMid:11208211.

15. Marino CEB and Mascaro LH. Electrochemical tests to evaluate the stability of the anodic films on dental implants. International Journal of Electrochemistry. 2011; 2011:1-7. http://dx.doi. org/10.4061/2011/574502.

16. Marino CEB and Mascaro LH. EIS characterization of a Tidental implant in artificial saliva media: Dissolution process of the oxide barrier. Journal of Electroanalytical Chemistry. 2004; 568:115-120. http://dx.doi.org/10.1016/j.jelechem.2004.01.011.

17. Milošev I, Kosec T and Strehblow HH. XPS and EIS study of the passive film formed on orthopaedic Ti-6Al-7Nb alloy in Hank's physiological solution. Electrochimica Acta. 2008; 53(9):35473558. http://dx.doi.org/10.1016/j.electacta.2007.12.041.

18. Mansfeld F. Analysis and interpretation of EIS data for metals and alloys. Los Angeles: Solartron Limited; 1999.

19. Yu WQ, Qiu J and Zhang FQ. In vitro corrosion study of different TiO2 nanotube layers on titanium in solution with serum proteins. Colloids and Surfaces. B, Biointerfaces. 2011; 84(2):400-405. http://dx.doi.org/10.1016/j.colsurfb.2011.01.033. PMid:21377339.

20. Pan J, Thierry D and Leygraf C. Electrochemical impedance spectroscopy study of the passive oxide film on titanium for implant application. Electrochimica Acta. 1996; 41(7-8):11431153. http://dx.doi.org/10.1016/0013-4686(95)00465-3.

21. Oliveira NTC and Guastaldi AC. Electrochemical stability and corrosion resistance of Ti-Mo alloys for biomedical applications. Acta Biomaterialia. 2009; 5(1):399-405. http:// dx.doi.org/10.1016/j.actbio.2008.07.010. PMid:18707926.

22. Souza MEP, Lima L, Lima CRP, Zavaglia CAC and Freire CMA. Effects of $\mathrm{pH}$ on the electrochemical behaviour of titanium alloys for implant applications. Journal of Materials Science. Materials in Medicine. 2009; 20(2):549-552. http:// dx.doi.org/10.1007/s10856-008-3623-y. PMid:18987951.

23. Songür M, Çelikkan H, Gökmeşe F, Şimşek SA, Altun NŞ and Aksu ML. Electrochemical corrosion properties of metal alloys used in orthopaedic implants. Journal of Applied Electrochemistry. 2009; 39(8):1259-1265. http://dx.doi.org/10.1007/s10800-0099793-6.

24. Zhu X, Kim KH and Jeong Y. Anodic oxide films containing Ca and $\mathrm{P}$ of titanium biomaterial. Biomaterials. 2001; 22(16):21992206. http://dx.doi.org/10.1016/S0142-9612(00)00394-X. PMid:11456059.

25. Simka W, Sadkowski A, Warczak M, Iwaniak A, Dercz G, Michalska J, et al. Characterization of passive films formed on titanium during anodic oxidation. Electrochimica Acta. 2011; 56(24):8962-8968. http://dx.doi.org/10.1016/j.electacta.2011.07.129.

26. Sadat-Shojai M, Khorasani M-T, Dinpanah-Khoshdargi E and Jamshidi A. Synthesis methods for nanosized hydroxyapatite with diverse structures. Acta Biomaterialia. 2013; 9(8):7591-7621. http://dx.doi.org/10.1016/j.actbio.2013.04.012. PMid:23583646.

27. Kokubo T and Takadama H. How useful is SBF in predicting in vivo bone bioactivity? Biomaterials. 2006; 27(15):29072915. http://dx.doi.org/10.1016/j.biomaterials.2006.01.017. PMid: 16448693.

28. Liang YQ, Cui ZD, Zhu SL and Yang XJ. Characterization of self-organized $\mathrm{TiO} 2$ nanotubes on Ti-4Zr-22Nb-2Sn alloys and the application in drug delivery system. Journal of Materials Science. Materials in Medicine. 2011; 22(3):461-467. http:// dx.doi.org/10.1007/s10856-011-4234-6. PMid:21287247.

29. American Society for Testing and Materials - ASTM. F2129-08: Standard Test method for conducting cyclic potentiodynamic polarization measurements to determine the corrosion 
susceptibility of small implant devices. West Conshohocken; 2008. http://dx.doi.org/10.1520/F2129-08.

30. Ferdjani S, David D and Beranger G. Anodic oxidation of titanium in phosphoric acid baths: phosphorus incorporation into the oxide. Journal of Alloys and Compounds. 1993; 200(12):191-194. http://dx.doi.org/10.1016/0925-8388(93)90493-7.

31. Marino CEB, Biaggio SR, Rocha-Filho RC and Bocchi N. Voltammetric stability of anodic films on the Ti6A14V alloy in chloride medium. Electrochimica Acta. 2006; 51(28):65806583. http://dx.doi.org/10.1016/j.electacta.2006.04.051.

32. Macdonald JR. Impedance spectroscopy. Annals of Biomedical Engineering. 1992; 20(3):289-305. http://dx.doi.org/10.1007/ BF02368532. PMid:1443825.
33. Arslan H, Çelikkan H, Örnek N, Ozan O, Ersoy AE and Aksu ML. Galvanic corrosion of titanium-based dental implant material. Journal of Applied Electrochemistry. 2008; 38(6):853859. http://dx.doi.org/10.1007/s10800-008-9523-5.

34. Venugopalan R, Weimer JJ, George MA and Lucas LC. The effect of nitrogen diffusion hardening on the surface chemistry and scratch resistance of Ti-6A1-4V alloy. Biomaterials. 2000; 21(16):1669-1677. http://dx.doi.org/10.1016/S01429612(00)00049-1. PMid:10905408.

35. Walter GW. A review of impedance plot methods used for corrosion performance analysis of painted metals. Corrosion Science. 1986; 26(9):681-703. http://dx.doi.org/10.1016/0010938X(86)90033-8.

36. Aoki H. Science and medical applications of hydroxyapatite. Tokyo: JAAS; 1991. 